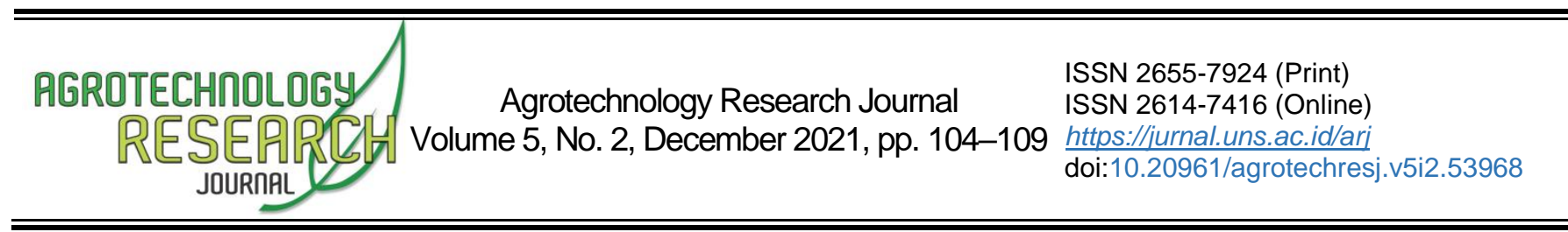

\title{
Growth and Yield of Soybeans in Various Growing Media Composition and Inoculation of Rhizobacteria on Marginal Soils
}

\author{
Aditya Aris Kurniawan ${ }^{1}$, Pauliz Budi Hastuti ${ }^{*}$, Arif Umami ${ }^{3}$ \\ ${ }^{1-3}$ Faculty of Agriculture, Institut Pertanian Stiper, Sleman, Daerah Istimewa Yogyakarta 55281, Indonesia
}

Received 30 July 2021; Accepted 29 September 2021; Published 31 December 2021

\begin{abstract}
Soybean is one of the leading commodities that is being developed in Indonesia. Today, the increase of soybean needs is not followed by its production capacity. Meanwhile, the area of productive land for soybean farming is decreasing due to land conversion for non-agricultural needs. One effort that can be an alternative is using marginal land by applying appropriate technology such as manure and biofertilizer. So that, it was necessary to know the composition of manure and biofertilizer, which was appropriate to increase the growth and yield of soybean plants on marginal soils. Complete Randomized Design was used in the experiment with two factors. The first factor was the ratio of manure: soil ( $\mathrm{v}: \mathrm{v})$ there are $0: 1,1: 1,1: 2$, and 2:1. The second factor was rhizobacteria inoculum, which included without rhizobacteria, exogenous rhizobacteria, and indigenous rhizobacteria. Results showed that the composition of the best planting medium for growth and yield of soybean is manure: soil 1:1 and 1:2. The source of the rhizobacteria inoculum is not a significant difference to the soybean's growth and yield. Manure and soil 1:2 with indigenous inoculum tended to produce the best total number of nodules and effective root nodules. Manure and soil 1:1 with indigenous inoculum produce the best of seeds number. Manure and soil 1:2 or 2:1 with exogenous inoculum tended to produce the best seed index weight (g per 100 seeds).
\end{abstract}

Keywords: biofertilizer; Glycine max; manure; marginal soil; media composition

Cite this as (CSE Style): Kurniawan AA, Hastuti PB, Umami A. 2021. Growth and yield of soybeans in various growing media composition and inoculation of rhizobacteria on marginal soils. Agrotechnology Res J. 5(2):104-109. https://dx.doi.org/10.20961/agrotechresj.v5i2.53968.

\section{INTRODUCTION}

Soybean (Glycine max (L) Merril.) is a food crop widely known by the community because it is a source of vegetable protein at an affordable price by most people. The demand for soybeans in Indonesia as food is very high at 2,18 million tons in 2014 and 2,32 million tons in 2015. Meanwhile, soybean production in 2015 was 963,183 tons, so the shortage of these needs must be met from imports. The increase in soybean production was sustained by adding the harvested area of around 24,670 hectares or $4.01 \%$ (BPS 2015). Marginal land can be interpreted as low-quality land because it has several limiting factors if used for certain purposes (latosol soil). The limiting factor can be overcome by input or costs that must be spent. Common problems in latosol soil are acid soil reactions, low organic matter content, low nutrient availability and reserves, and high Al saturation (Maas et al. 2020; Ikhwani et al. 2021; Wardani et al. 2021; Wei et al. 2021). The typical reaction of this soil will impact increasing Al content, which is toxic to plants, besides affecting $P$ availability because $P$ is fixed in the form of

${ }^{*}$ Corresponding Author:

E-Mail: pauliz@instiperjogja.ac.id
Al-P (Widawati dan Suliasih 2020; Fernandes et al. 2021; Minardi et al. 2021). Therefore, a necessary effort needs to be found as an alternative to improve soil fertility and optimize the management of soil organic matter (Diptaningsari dan Rivaie 2021; Thapa et al. 2021).

Organic fertilizers are the best natural soil enhancers rather than artificial or synthetic enhancers. In general, organic fertilizers contain not only low macronutrients but also contain sufficient amounts of micronutrients which are very necessary for plant growth. One livestock that has the potential as a source of organic fertilizer is goats. In previous studies, Luo et al. (2021) found that the addition of goat manure at the ratio of $1: 2$ and $1: 1(\mathrm{v}: \mathrm{v})$ showed a significant effect on the addition of fresh leaves weight the kailan plant. Tayyab et al. (2018) reported that applying goat manure and urea to alfisols could increase the yield of red chilies, a combination of $25 \% \mathrm{~N}$ goat manure and $75 \% \mathrm{~N}$ urea produced red chilies of 10.92 t/ha with an increase of $20,35 \%$.

In agriculture, microbes as biological fertilizers are essential because they play a role in food security and sustainable crop production (Gerrewey et al. 2020). Added by (Jabborova et al. 2021), biological nitrogen fixation (BNF) is a nitrogen fixation process in an agricultural system that is inexpensive and environmentally friendly. Many research results show the 
positive effect of inoculation in increasing BNF (Budiastuti et al. 2021).

If the necessary rhizobia strain is not present in the soil, then inoculation in legumes with the appropriate rhizobia is essential (Meng et al. 2015). The research results by Sánchez-Chino et al. (2015) showed that Legume fix on soybean plants in all research locations increased the yield by $50 \%$ against control and, when combined with Teprosyn Mo, could increase the yield by 205.62\%.

Previous experiments have shown that inoculation of legumes provides a considerable opportunity to increase the production of legumes both in quality and quantity, also reduces the use of artificial fertilizers (Wu et al. 2005; Konvalinková et al. 2017; Ferrarezi et al. 2022). Inoculum originating from ex-soybean farming soil still has many bacteria and is cheap, so it is crucial to investigate its effect on soybean growth and yield. The objective of this study was to know the composition of manure and biofertilizer, which was appropriate to increase the growth and yield of soybean plants on marginal soils.

\section{MATERIALS AND METHODS \\ Experimental site}

The research has been carried out from February 2018 to May 2018 in an Education and Research Gardens at Stiper Agricultural Institute in Sleman, Yogyakarta, Indonesia.

\section{Materials}

The materials used were Anjasmoro cultivar, goat manure as organic fertilizer, latosol soil as growing media, polybags, plastic, commercial rhizobacteria (Rhizobium sp, Pseudomonas sp, and Bacillus sp) as exogenous rhizobacteria.

\section{Growing media preparation and rhizobacteria inoculation}

Latosol soil ( $\mathrm{pH}$ 5.5) from Patuk, Gunung Kidul, Yogyakarta was used as growing media in polybags $30 \times 30 \mathrm{~cm}$. The ratio of manure: the soil is described below. Inoculating rhizobacteria is done by mixing the seeds in rhizoka (1 g per $200 \mathrm{~g}$ of seeds); previously, the seeds are moistened with water. Seeds then were planted in growing media. Meanwhile, indigenous rhizobacteria source was obtained from ex-soybean farming soil. Inorganic fertilizer was only used for treatments without manure.

\section{Harvest and data collection}

Root nodule and chlorophylls total were measured 30 days after planting (DAP). Measurement of chlorophylls totals used Minolta SPAD. Harvest was performed 90 DAP and measurement of plant height, fresh plant weight, plant dry weight, fresh root weight, root dry weight, seed weight total per plant, seed weight per 100 seeds, pod number, and pod weight.

\section{Experimental design}

The study was conducted using a Factorial design arranged in a Completely Randomized Design (CRD) consisting of 2 factors. The first factor was the ratio of manure: soil (v:v) including $0: 1,1: 1,1: 2$, and 2:1. The second factor was rhizobacteria inoculum, which included without rhizobacteria, exogenous rhizobacteria, and indigenous rhizobacteria. So, there are 12 combinations treatments; each combination was replicated seven times.

\section{Statistical analysis}

The data were analyzed by ANOVA (Analysis of Variance) using the SPSS program. Duncan's Multiple Range Test (DMRT) determined the differences among treatment means at $\mathrm{P}<0.05$.

\section{RESULTS AND DISCUSSION \\ Soybean's growth on marginal soil}

The results showed that the composition of the growing medium had a significant effect on plant height, total chlorophyll, plant fresh weight, plant dry weight, fresh root weight, root dry weight, and nodule weight (Table 1). Meanwhile, variation of rhizobacteria inoculum source had no significant effect on soybean growth. So that, the composition of manure and soil 1:1 and 1:2 generally indicated appropriate for soybean's growth. Nevertheless, the interaction between manure and soil ratio (v:v) and rhizobacteria inoculation was shown in nodule number and adequate nodule number (Table 2).

The composition of the growing medium had a significant effect on plant height, total chlorophyll, plant fresh weight, plant dry weight, fresh root weight, root dry weight, and nodule weight (Table 1). The composition of manure: soil ratio 1:1 and 1: 2 generally indicated appropriate for soybean's growth. The provision of manure on latosol soil has excellent benefits, such as the availability of more $P$ elements. This is because the results of the decomposition of organic matter in the form of humic acids that form chelate bonds with $\mathrm{Al}$ and $\mathrm{Fe}$ ions can reduce the solubility of $\mathrm{Al}$ and $\mathrm{Fe}$ ions and also release $P$, which is fixed by $A$ and $F e$ so that $P$ availability increases (Tonks et al. 2017; Grzyb et al. 2021; Sukmasari et al. 2021). Organic matter would improve cation exchange capacity (CEC) and form a chelated cation (Sudadi et al. 2018; Agus et al. 2019; Dai et al. 2020). Therefore, the addition of organic matter to marginal land is needed.

The variation of rhizobacteria inoculum source had no significant effect on soybean growth and yield (data not shown). This means that the treatment without the bacteria gave the same soybean growth and yield as that given the inoculum. Treatment of manure: soil ratio 1: 2 with indigenous inoculum tended to produce the best total number of nodules and effective root nodules (Table 2). This shows that the inoculum originating from the soil previously planted with soybeans still contains a lot of effective Rhizobium bacteria. Indigenous Rhizobium sp inoculated can form nodules, but not all inoculants are effective for soybean plants (Abd-Alla et al. 2014; Banerjee et al. 2016; Goyal and Goel 2018; Franzini et al. 2019; Ilangumaran et al. 2021). Rhizobium bacteria are soil microbes capable of binding free nitrogen in the air into ammonia $\left(\mathrm{NH}_{3}\right)$, which will be converted into amino acids become nitrogen compounds needed by plants to grow and develop (Tilak et al. 2006; Ahmed et al. 2016; Ren et al. 2019). 


\section{Yield production of Soybean}

The result (Table 3 ) shows that the composition of manure: soil ratio ( $v: v) 1: 1,1: 2$, and $2: 1$ generally gives better results than $0: 1+$ NPK for soybean's production yield. Besides these benefits, manure can also improve the physical properties of the soil. Organic matter makes the soil loose and crumb so that aeration and thinning are better and easier to penetrate the roots of plants. Previous research shows that providing solid compost or manure can increase plant height, number of flowers, number of pods, number of nodules, dry weight of stover, root dry weight, protein content, and seed fat soybean plants (Endriani et al. 2021; Latawiec et al. 2021; Zumpf et al. 2021)

Kinds of rhizobacteria inoculation resulted in the same seed weight, pods number, and pods weight of soybean on marginal soil. The number of pods is not followed by seed formation or filling because of many empty pods, as seen from the low seed weight.
Inoculants do not always increase soybean yield (De Gregorio et al. 2017; Widawati dan Suliasih 2020; Sahile et al. 2021). Several researchers had reported that the effectiveness of inoculants was reduced when soil conditions after planting were very dry or too wet or when soil $\mathrm{pH}$ was below 6.0. In this study, the $\mathrm{pH}$ of the latosol soil used was 5.5 .

The result (Table 4) shows that manure and soil $(0: 1)$ + NPK, without inoculum, are low in 100 seed index weight because of the low number of effective nodules formation. According to Khan et al. (2020), the number of nodules is an indicator of successful Rhizobium inoculation, which is often used to assess its effect on the growth and yield of soybean plants. Treatment of Manure: Soil $(0: 1)+N P K$ + without inoculum shows that pod and seed formation is inhibited due to the low number of effective root nodules. This indicates that many pods are hollow, as indicated by the low seed index weight.

Table 1. Soybean's growth on marginal soil with variation of manure

\begin{tabular}{lcccc}
\hline \multirow{2}{*}{ Variables } & \multicolumn{4}{c}{ Menure: Soil ratio (v:v) } \\
\cline { 2 - 5 } & $0: 1+$ NPK & $1: 1$ & $1: 2$ & $2: 1$ \\
\hline Plant height $(\mathrm{cm})$ & $36.00 \pm 1.21 \mathrm{c}$ & $43.50 \pm 1.24 \mathrm{~b}$ & $53.17 \pm 1.67 \mathrm{a}$ & $37.83 \pm 1.23 \mathrm{c}$ \\
Chlorophylls $(\mathrm{U})$ & $36.31 \pm 0.55 \mathrm{a}$ & $34.22 \pm 0.81 \mathrm{a}$ & $34.67 \pm 0.70 \mathrm{a}$ & $29.72 \pm 1.62 \mathrm{~b}$ \\
Plant fresh weight $(\mathrm{g})$ & $23.77 \pm 0.92 \mathrm{c}$ & $37.18 \pm 1.92 \mathrm{ab}$ & $38.58 \pm 2.35 \mathrm{a}$ & $32.21 \pm 2.75 \mathrm{~b}$ \\
Plant dry weight $(\mathrm{g})$ & $19.50 \pm 0.71 \mathrm{c}$ & $28.51 \pm 1.20 \mathrm{a}$ & $29.38 \pm 1.63 \mathrm{a}$ & $23.69 \pm 1.96 \mathrm{~b}$ \\
Root Fresh weight $(\mathrm{g})$ & $6.16 \pm 0.29 \mathrm{~b}$ & $6.98 \pm 0.29 \mathrm{ab}$ & $7.92 \pm 0.30 \mathrm{a}$ & $6.47 \pm 0.44 \mathrm{~b}$ \\
Root dry weight $(\mathrm{g})$ & $5.55 \pm 0.25 \mathrm{~b}$ & $6.22 \pm 0.25 \mathrm{~b}$ & $7.06 \pm 0.25 \mathrm{a}$ & $5.85 \pm 0.37 \mathrm{~b}$ \\
Nodules weight $(\mathrm{g})$ & $0.90 \pm 0.15 \mathrm{c}$ & $2.26 \pm 0.23 \mathrm{~b}$ & $3.91 \pm 0.09 \mathrm{a}$ & $0.97 \pm 0.28 \mathrm{c}$ \\
\hline
\end{tabular}

Remarks: Means followed by the same letter on the line indicate no significant differences based on Duncan's Multiple Range Test at $p<0.05$.

Table 2. Soybean's nodules on variation of manure: soil ratio (v:v) and rhizobacteria inoculation

\begin{tabular}{lcl}
\hline Treatments & Nodule numbers & \multicolumn{1}{c}{ Effective nodules } \\
\hline Manure : Soil $(0: 1)+$ without inoculum & $25.00 \pm 6.03 \mathrm{ef}$ & $20.33 \pm 5.69 \mathrm{ef}$ \\
Manure : Soil $(0: 1)+$ exogenous rhizobacteria & $50.00 \pm 12.34 \mathrm{~cd}$ & $48.67 \pm 11.46 \mathrm{~cd}$ \\
Manure : Soil $(0: 1)+$ indigenous rhizobacteria & $36.00 \pm 5.85 \mathrm{de}$ & $32.67 \pm 5.46 \mathrm{de}$ \\
Manure : Soil $(1: 1)+$ without inoculum & $61.67 \pm 14.24 \mathrm{bcd}$ & $59.67 \pm 13.25 \mathrm{bcd}$ \\
Manure : Soil $(1: 1)+$ exogenous rhizobacteria & $49.67 \pm 2.96 \mathrm{~cd}$ & $48.33 \pm 2.73 \mathrm{~cd}$ \\
Manure : Soil $(1: 1)+$ indigenous rhizobacteria & $86.67 \pm 28.04 \mathrm{abc}$ & $83.33 \pm 27.72 \mathrm{abc}$ \\
Manure : Soil $(1: 2)+$ without inoculum & $88.67 \pm 3.28 \mathrm{abc}$ & $84.33 \pm 2.03 \mathrm{abc}$ \\
Manure : Soil $(1: 2)+$ exogenous rhizobacteria & $105.33 \pm 4.37 \mathrm{ab}$ & $103.00 \pm 3.06 \mathrm{ab}$ \\
Manure : Soil $(1: 2)+$ indigenous rhizobacteria & $121.00 \pm 14.18 \mathrm{a}$ & $117.33 \pm 13.37 \mathrm{a}$ \\
Manure : Soil $(2: 1)+$ without inoculum & $18.33 \pm 3.33 \mathrm{f}$ & $14.00 \pm 3.51 \mathrm{f}$ \\
Manure : Soil $(2: 1)+$ exogenous rhizobacteria & $14.00 \pm 1.53 \mathrm{f}$ & $11.67 \pm 2.19 \mathrm{f}$ \\
Manure : Soil $(2: 1)+$ indigenous rhizobacteria & $57.00 \pm 16.50 \mathrm{~cd}$ & $57.00 \pm 13.65 \mathrm{bcd}$ \\
\hline
\end{tabular}

Remarks: Means followed by the same letter on the line indicate no significant differences based on Duncan's Multiple Range Test at $p<0.05$. 
Table 3. Pods number, pods weight and seed weight of soybean on marginal soil with variation of manure : soil ratio (v:v)

\begin{tabular}{lcccc}
\hline \multirow{2}{*}{ Variables } & \multicolumn{4}{c}{ Manure: Soil ratio (v:v) } \\
\cline { 2 - 5 } & $0: 1+$ NPK & $1: 1$ & $1: 2$ & $2: 1$ \\
\hline Pods number & $31.00 \pm 1.77 \mathrm{c}$ & $45.17 \pm 2.33 \mathrm{a}$ & $38.42 \pm 1.47 \mathrm{ab}$ & $33.83 \pm 1.59 \mathrm{bc}$ \\
Pods weight & $18.47 \pm 1.04 \mathrm{~b}$ & $28.48 \pm 2.97 \mathrm{a}$ & $27.93 \pm 3.05 \mathrm{a}$ & $22.39 \pm 1.35 \mathrm{ab}$ \\
Seed weight total $(\mathrm{g})$ & $10.60 \pm 0.90 \mathrm{c}$ & $15.04 \pm 1.19 \mathrm{a}$ & $12.87 \pm 1.58 \mathrm{ab}$ & $12.87 \pm 1.29 \mathrm{ab}$ \\
\hline
\end{tabular}

Remarks: Means followed by the same letter on the line indicate no significant differences based on Duncan's Multiple Range Test at $p<0.05$.

Table 4. Soybean's seed number and seed index weight (g per 100 seeds) on variation of manure: soil ratio $(\mathrm{v}: \mathrm{v})$ and rhizobacteria inoculation

\begin{tabular}{lll}
\hline Treatments & Seeds Number & $\begin{array}{c}\text { Seed Index Weight } \\
\text { (G/100 Seeds) }\end{array}$ \\
\hline Manure : Soil $(0: 1)+$ without inoculum & $55.5 \pm 4.35 \mathrm{abc}$ & $17.13 \pm 1.56 \mathrm{c}$ \\
Manure : Soil $(0: 1)+$ exogenous rhizobacteria & $57.5 \pm 4.11 \mathrm{abc}$ & $17.59 \pm 1.87 \mathrm{c}$ \\
Manure : Soil $(0: 1)+$ indigenous rhizobacteria & $41.00 \pm 3.76 \mathrm{c}$ & $24.97 \pm 3.48 \mathrm{ab}$ \\
Manure : Soil $(1: 1)+$ without inoculum & $49.25 \pm 8.73 \mathrm{bc}$ & $25.37 \pm 0.59 \mathrm{ab}$ \\
Manure : Soil $(1: 1)+$ exogenous rhizobacteria & $65.75 \pm 9.02 \mathrm{ab}$ & $24.52 \pm 5.67 \mathrm{abc}$ \\
Manure : Soil $(1: 1)+$ indigenous rhizobacteria & $84.00 \pm 6.38 \mathrm{a}$ & $21.29 \pm 2.19 \mathrm{abc}$ \\
Manure : Soil $(1: 2)+$ without inoculum & $51.75 \pm 1.44 \mathrm{bc}$ & $23.55 \pm 1.53 \mathrm{abc}$ \\
Manure : Soil $(1: 2)+$ exogenous rhizobacteria & $58.50 \pm 10.63 \mathrm{abc}$ & $28.67 \pm 4.32 \mathrm{a}$ \\
Manure : Soil $(1: 2)+$ indigenous rhizobacteria & $38.50 \pm 2.96 \mathrm{c}$ & $24.73 \pm 1.45 \mathrm{ab}$ \\
Manure : Soil $(2: 1)+$ without inoculum & $55.75 \pm 3.75 \mathrm{abc}$ & $20.51 \pm 0.87 \mathrm{abc}$ \\
Manure : Soil $(2: 1)+$ exogenous rhizobacteria & $47.25 \pm 5.85 \mathrm{bc}$ & $28.51 \pm 2.44 \mathrm{a}$ \\
Manure : Soil $(2: 1)+$ indigenous rhizobacteria & $71.50 \pm 18.05 \mathrm{ab}$ & $18.70 \pm 0.69 \mathrm{bc}$ \\
\hline
\end{tabular}

Remarks: Means followed by the same letter on the line indicate no significant differences based on Duncan's Multiple Range Test at $p<0.05$.

\section{CONCLUSIONS}

Results showed that the composition of the best planting medium for growth and yield of soybean is manure and soil ratio $1: 1$ and $1: 2$. The source of the rhizobacteria inoculum was no significance difference to the soybean's growth and yield. Treatment of manure and soil ratio 1:2 with indigenous inoculum tended to achieve the highest total number of nodules and effective root nodules of soybean. Manure and soil ratio 1:1 with indigenous inoculum produce the best of seeds number. Manure and soil ratio 1:2 or 2:1 with exogenous inoculum tended to produce the best seed index weight (g per 100 seeds).

\section{REFERENCES}

Abd-Alla MH, El-Enany AWE, Nafady NA, Khalaf DM, Morsy FM. 2014. Synergistic interaction of Rhizobium leguminosarum bv. viciae and arbuscular mycorrhizal fungi as a plant growth promoting biofertilizers for faba bean (Vicia faba L.) in alkaline soil. Microbiol Res.

http://dx.doi.org/10.1016/j.micres.2013.07.007.

Agus C, Hendryan A, Harianja V, Faridah E, Atmanto WD, Cahyanti $P A B$, Wulandaric $D$, Pertiwiningrum $A$, Suhartanto B, Bantara I, et al. 2019. Role of organic soil amendment of paramagnetic humus and compost for rehabilitation of post tin-mined tropical land. Int $\mathrm{J}$
Smart Grid Clean Energy. 8(5):556-561. https://doi.org/10.12720/sgce.8.5.556-561.

Ahmed I, Khan MA, Ahmed N, Khan N, Khan S, Yazdan F, Marwat S, Biosci IJ. 2016. Influence of Rhizobium inoculation on nodules, growth and yield of french beans cultivars. Int J Biosci. 9(6):226-233. https://doi.org/10.12692/ijb/9.6.226-233.

Banerjee S, Baah-Acheamfour M, Carlyle CN, Bissett A, Richardson AE, Siddique T, Bork EW, Chang SX. 2016. Determinants of bacterial communities in Canadian agroforestry systems. Environ Microbiol. 18(6):1805-1816. https://doi.org/10.1111/14622920.12986.

[BPS] Badan Pusat Statistik. 2015. Produksi kedelai menurut provinsi (ton), 1993-2015. Jakarta (ID): Badan Pusat Statistik Indonesia

Budiastuti MTS, Purnomo D, Supriyono, Pujiasmanto B, Setyaningrum D. 2021. Effects of light intensity and co-inoculation of arbuscular mycorrhizal fungi and rhizobium on root growth and nodulation of Indigofera tinctoria. Sains Tanah. 17(2):94-99. https://doi.org/10.20961/STJSSA.V17I2.40065.

Dai Y, Zheng H, Jiang Z, Xing B. 2020. Combined effects of biochar properties and soil conditions on plant growth: A meta-analysis. Sci Total Environ. 
713:136635. doi:10.1016/j.scitotenv.2020.136635. https://doi.org/10.1016/j.scitotenv.2020.136635.

Diptaningsari D, Rivaie AA. 2021. Comparison study of growth and yield of three soybean varieties on acid upland soil of South Lampung. IOP Conf Ser Earth Environ Sci. 648(1). https://doi.org/10.1088/17551315/648/1/012066.

Endriani, Rivaie AA, Barus J, Meithasari D, Asnawi R. 2021. Improving the quality of acid soils to increase soybean yields and farmer's incomes. IOP Conf Ser Earth Environ Sci. 648(1). https://doi.org/10.1088/1755-1315/648/1/012059.

Fernandes AM, Ribeiro NP, Assunção NS, Geibel da Silva Nunes J, Sorroche CP, Leonel M. 2021. Impact of nitrogen and green manure on yield and quality of sweet potato in sandy soil: A Brazilian case study. J Agric Food Res. 4:100131. https://doi.org/10.1016/j.jafr.2021.100131.

Ferrarezi JA, Carvalho-Estrada $P$ de $A$, Batista $B D$, Aniceto RM, Tschoeke BAP, Andrade PA de M, Lopes B de M, Bonatelli ML, Odisi EJ, Azevedo JL, et al. 2022. Effects of inoculation with plant growthpromoting rhizobacteria from the Brazilian Amazon on the bacterial community associated with maize in field. Appl Soil Ecol. 170(October 2021). https://doi.org/10.1016/j.apsoil.2021.104297.

Franzini VI, Azcón R, Ruiz-Lozano JM, Aroca R. 2019. Rhizobial symbiosis modifies root hydraulic properties in bean plants under non-stressed and salinity-stressed conditions. Planta. 249(4):12071215. https://doi.org/10.1007/s00425-018-03076-0.

Gerrewey TV, Vandecruys M, Ameloot N, Perneel M, van Labeke MC, Boon N, Geelen D. 2020. Microbe-plant growing media interactions modulate the effectiveness of bacterial amendments on lettuce Performance Inside a Plant Factory with Artificial Lighting. Agronomy. 10(10):1-23. https://doi.org/10.3390/agronomy10101456.

Goyal MR, Goel A. 2018. Role of Nanofertilizers in Sustainable Agriculture. Sustain Biol Syst Agric.(March):209-219.

https://doi.org/10.1201/9781315165264-9.

De Gregorio PR, Michavila G, Muller LR, De Souza Borges C, Pomares MF, De Sá ELS, Pereira C, Vincent PA. 2017. Benecial rhizobacteria immobilized in nano-bers for potential application as soybean seed bioinoculants. PLoS One. 12(5):1-22. https://doi.org/10.1371/journal.pone.0176930.

Grzyb A, Wolna-Maruwka A, Niewiadomska A. 2021. The Significance of Microbial Transformation of Nitrogen Compounds in the Light of Integrated Crop Management. Agronomy. 11(7):1415. https://doi.org/10.3390/agronomy11071415.

Ikhwani, Saribanon N, Setia TM, Yuniarti E, Jumakir. 2021. Nitrogen-fixation and phosphate-solubilization bacteria isolated from alluvial and latosol soil paddy field. Biodiversitas. 22(11):4722-4730. llangumaran G, Schwinghamer TD, Smith DL. 2021. Rhizobacteria From Root Nodules of an Indigenous Legume Enhance Salinity Stress Tolerance in Soybean. Front Sustain Food Syst. 4(January). https://doi.org/10.3389/fsufs.2020.617978.

Jabborova D, Kannepalli A, Davranov K, Narimanov A, Enakiev Y, Syed A, Elgorban AM, Bahkali AH, Wirth S, Sayyed RZ, et al. 2021. Co-inoculation of rhizobacteria promotes growth, yield, and nutrient contents in soybean and improves soil enzymes and nutrients under drought conditions. Sci Rep. 11(1):19. https://doi.org/10.1038/s41598-021-01337-9.

Khan N, Ali S, Tariq H, Latif S, Yasmin H, Mehmood A, Shahid MA. 2020. Water conservation and plant survival strategies of rhizobacteria under drought stress. $\quad$ Agronomy. 10(11):1-23. https://doi.org/10.3390/agronomy10111683.

Konvalinková T, Püschel D, Řezáčová V, Gryndlerová H, Jansa J. 2017. Carbon flow from plant to arbuscular mycorrhizal fungi is reduced under phosphorus fertilization. Plant Soil. 419(1-2):319-333. https://doi.org/10.1007/s11104-017-3350-6.

Latawiec AE, Koryś A, Koryś KA, Kuboń M, Sadowska $U$, Gliniak $M$, Sikora J, Drosik A, Niemiec M, Klimek-Kopyra A, et al. 2021. Economic analysis of biochar use in soybean production in Poland. Agronomy. 11(11):2108. https://doi.org/10.3390/agronomy11112108.

Luo S, Zhen Z, Zhu X, Ren L, Wu W, Zhang W, Chen Y, Zhang D, Song Z, Lin Z, et al. 2021. Accelerated atrazine degradation and altered metabolic pathways in goat manure assisted soil bioremediation. Ecotoxicol Environ 221. https://doi.org/10.1016/j.ecoenv.2021.112432.

Maas KDB, dos Santos Weber OL, Scaramuzza JF, Vieira CR. 2020. Biosolid in the chemical and physical attributes of a typical dystrophic red latosol. Floresta e Ambient. 27(4). https://doi.org/10.1590/21798087.032118.

Meng L, Zhang A, Wang F, Han X, Wang D, Li S. 2015. Arbuscular mycorrhizal fungi and rhizobium facilitate nitrogen uptake and transfer in soybean/maize intercropping system. Front Plant Sci. 6(MAY):1-10. https://doi.org/10.3389/fpls.2015.00339.

Minardi S, Haniati IL, Harieni S, Sudadi, Cahyono O, Suryono. 2021. Effect of phosphorus and calcium availability as influenced by manure, rock phosphate, and dolomite on soybean yield. IOP Conf Ser Earth Environ Sci. 828(1). https://doi.org/10.1088/17551315/828/1/012012.

Ren CG, Kong CC, Wang SX, Xie ZH. 2019. Enhanced phytoremediation of uranium-contaminated soils by arbuscular mycorrhiza and rhizobium. Chemosphere. 217:773-779. https://doi.org/10.1016/j.chemosphere.2018.11.085.

Sahile AA, Khan MA, Hamayun M, Imran M, Kang S-M, Lee I-J. 2021. Novel Bacillus cereus Strain, ALT1, Enhance Growth and Strengthens the Antioxidant 
System of Soybean under Cadmium Stress. Agronomy. 11(2):404 https://doi.org/10.3390/agronomy11020404.

Sánchez-Chino X, Jiménez-Martínez C, Dávila-Ortiz G, Álvarez-González I, Madrigal-Bujaidar E. 2015. Nutrient and nonnutrient components of legumes, and its chemopreventive activity: A review. Nutr Cancer. 67(3):401-410. https://doi.org/10.1080/01635581.2015.1004729.

Sudadi, Suryono, Triharyanto E. 2018. The application of biofilm biofertilizer-based organic fertilizer to increase available soil nutrients and spinach yield on dry land (a study case in Lithosol soil type). IOP Conf Ser Earth Environ Sci. https://doi.org/10.1088/1755-1315/200/1/012006.

Sukmasari MD, Dani U, Wijaya AA. 2021. Arbuscular mycorrhiza inoculation for increasing the tolerance index and productivity of soybean on marginal soils. IOP Conf Ser Earth Environ Sci. 748(1). https://doi.org/10.1088/1755-1315/748/1/012043.

Tayyab M, Islam W, Arafat Y, Pang Z, Zhang C, Lin Y, Waqas M, Lin S, Lin W, Zhang H. 2018. Effect of sugarcane straw and goat manure on soil nutrient transformation and bacterial communities. Sustain. 10(7):1-21. https://doi.org/10.3390/su10072361.

Thapa S, Bhandari A, Ghimire R, Xue Q, Kidwaro F, Ghatrehsamani S, Maharjan B, Goodwin M. 2021. Managing micronutrients for improving soil fertility, health, and soybean yield. Sustain. 13(21):1-15. https://doi.org/10.3390/su132111766.

Tilak KVBR, Ranganayaki N, Manoharachari C. 2006. Synergistic effects of plant-growth promoting rhizobacteria and Rhizobium on nodulation and nitrogen fixation by pigeonpea (Cajanus cajan). Eur $\mathrm{J}$ Soil Sci. 57(1):67-71. https://doi.org/10.1111/j.13652389.2006.00771.x.
Tonks AJ, Aplin P, Beriro DJ, Cooper H, Evers S, Vane $\mathrm{CH}$, Sjögersten S. 2017. Impacts of conversion of tropical peat swamp forest to oil palm plantation on peat organic chemistry, physical properties and carbon stocks. Geoderma. 289:36-45. https://doi.org/10.1016/j.geoderma.2016.11.018.

Wardani IK, Suwardi, Sumawinata B. 2021. Characterization of steel slag and its effect on rice production in Latosol and acid sulfate soil. IOP Conf Ser Earth Environ Sci. 694(1). https://doi.org/10.1088/1755-1315/694/1/012056.

Wei C, Qiao J, Ma Z, Ma H, Tang X, Zhao W, Yan Q, Tang L, Du L. 2021. Stylo grass affecting soil respiration in latosol guava orchard of southern subtropical region of China. Agron J. 113(2):721-733. https://doi.org/10.1002/agj2.20437.

Widawati S, Suliasih. 2020. Comprehensive test of rhizobacteria as biostimulant, vesicular arbuscular mycorhizza (VAM) and graded dose of NPK fertilizer on the growth of bok choy (Brassica rapa L.). IOP Conf Ser Earth Environ Sci. 572(1). https://doi.org/10.1088/1755-1315/572/1/012023.

Wu SC, Cao ZH, Li ZG, Cheung KC, Wong MH. 2005. Effects of biofertilizer containing $\mathrm{N}$-fixer, $\mathrm{P}$ and $\mathrm{K}$ solubilizers and AM fungi on maize growth: $A$ greenhouse trial. Geoderma. 125(1-2):155-166. https://doi.org/10.1016/j.geoderma.2004.07.003.

Zumpf C, Cacho J, Grasse N, Quinn J, Hampton-Marcell J, Armstrong A, Campbell P, Negri MC, Lee DK. 2021. Influence of shrub willow buffers strategically integrated in an Illinois corn-soybean field on soil health and microbial community composition. Sci Total Environ. 772:145674. https://doi.org/10.1016/j.scitotenv.2021.145674. 